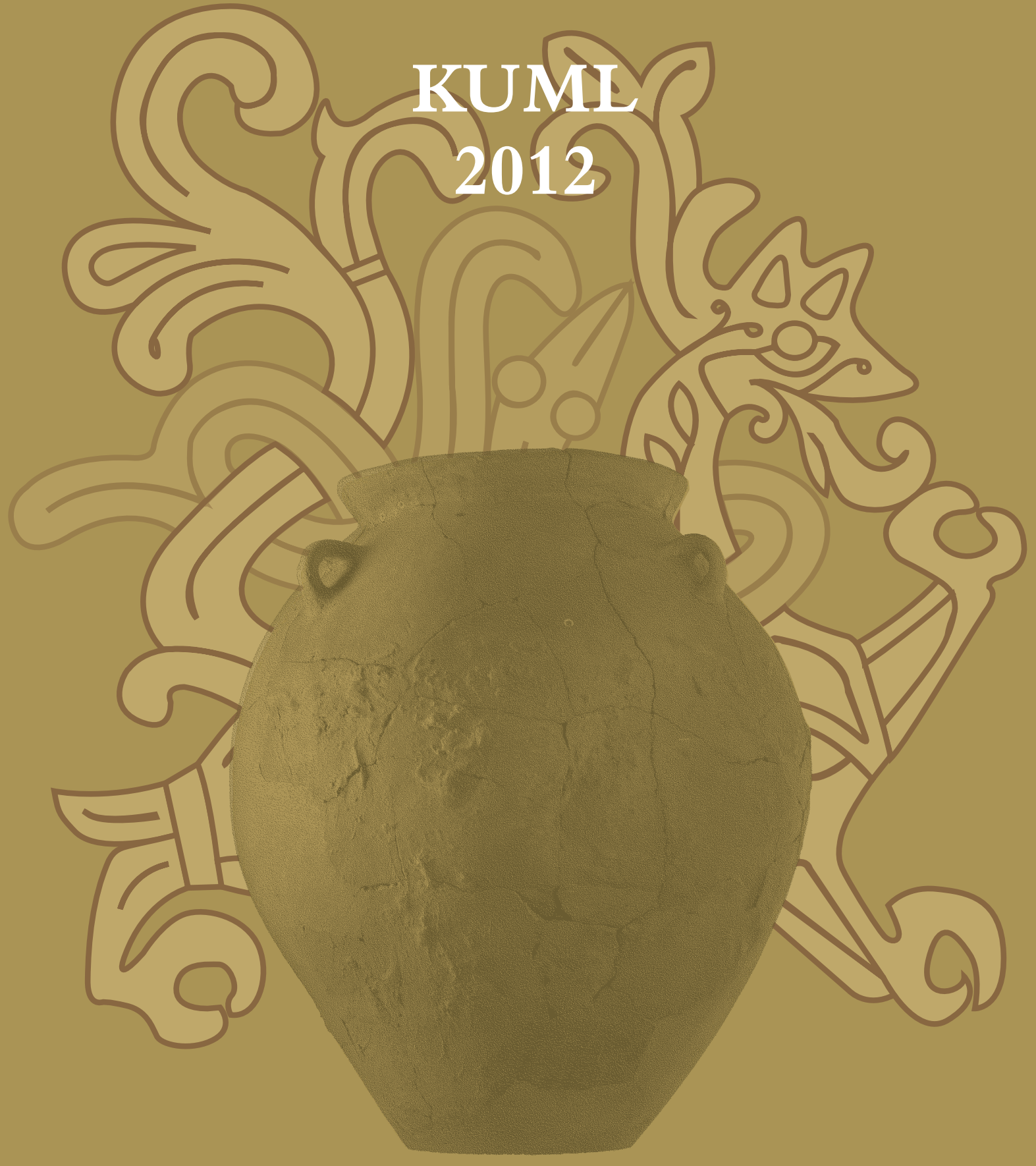




\section{KUML 2012}

Årbog for Jysk Arkæologisk Selskab

With summaries in English

I kommission hos Aarhus Universitetsforlag 


\title{
En keramiktraditions begyndelse Senmiddelalderens keramikproduktion og sociale forandringer
}

\author{
Af LONE CLAUDI-HANSEN
}

Swot' pot'er - eller jydepotter, som folk uden for produktionsområderne kaldte dem - var i mange år uundværlige i husholdninger landet over. Det gråsorte, jyske lertøj blev brændt i mile og fremstillet over en lang periode fra ca. år 1400-1900. Særligt i 1600-1700-tallet var der tale om en omfattende produktion, hvor pottefremstillingen i dele af Vestjylland udgjorde et afgørende bierhverv med en veletableret eksport til blandt andet Hamborg. ${ }^{1}$ Denne keramiktradition var i formforråd og fremstillingsmetoder præget af stor stabilitet i 500 år. Men hvordan traditionen begyndte, og hvordan produktionen af jydepotter kunne afløse den mere professionelle produktion af hårdt brændte, grå kuglepotter i starten af 1400-tallet, står uafklaret hen.

Fremstillingen af jydepotter er tidligere ofte blevet beskrevet som en forlængelse af oldtidens, særligt jernalderens, pottemageri. ${ }^{2}$ Det er ligheder både i de tekniske aspekter af karrenes fremstilling og i selve udformningen og dekorationen af karrene, der har været fremhævet som begrundelse for en kontinuerende produktionsform fra oldtidens keramikproduktion til introduktionen af jydepotter. Men med det store tidsmæssige spænd er denne sammenligning også et udtryk for en tendens til at anskue de tekniske dele af keramikfremstillingen som styret af økonomiske, funktionelle og naturgivne forhold og i mindre grad af kulturelle og andre sociale omstændigheder.

Først i den sidste snes år er der fremkommet blødt brændt keramik fra højmiddelalderen. ${ }^{3}$ Tilstedeværelsen af denne godstype peger på, at der har fundet en husholdningsproduktion af keramik sted i 1200-1300-tallet, sideløbende med den professionelle produktion af hårdt brændt keramik. Det sandsynliggør, at der kan have været tale om en fremstilling af milebrændt keramik fra høj- til senmiddelalder. ${ }^{4}$ Men hvis der også i 1200-1300-tallet - efter keramikovnens og drejeskivens introduktion - har eksisteret en produktion af blødt til mellemhårdt brændt gråvare frem til jydepottefremstillingen begynder, hvorfor ser vi det så ikke tydeligere i det arkæologiske materiale? Hvad er omfanget 
og karakteren af den hjemlige gråbrændte keramikproduktion omkring år 1400, og hvordan relaterer skiftet i fremstillingsteknikker med sociale forhold? På baggrund af publiceret arkæologisk og historisk materiale anskues i det følgende ændringen i produktionsformer for den gråbrændte husholdningskeramik omkring år $1400 \mathrm{i}$ lyset af samtidige samfundsmæssige forandringer.

\section{Jydepotten}

Den yngre produktion af jydepotter var overvejende centreret i fire egne af Jylland, nemlig Vendsyssel, Fjends (ved Limfjorden), Vorup (ved Randers) og Varde, med forskellige karakteristika i form og fremstillingsmetoder, fig. 1. ${ }^{5}$ Kendetegnende for dem alle var, at karrene var af gråt til sort gods, der var opbygget $\mathrm{i}$ hånden. De var oftest fint magret med sand og kunne være deko-

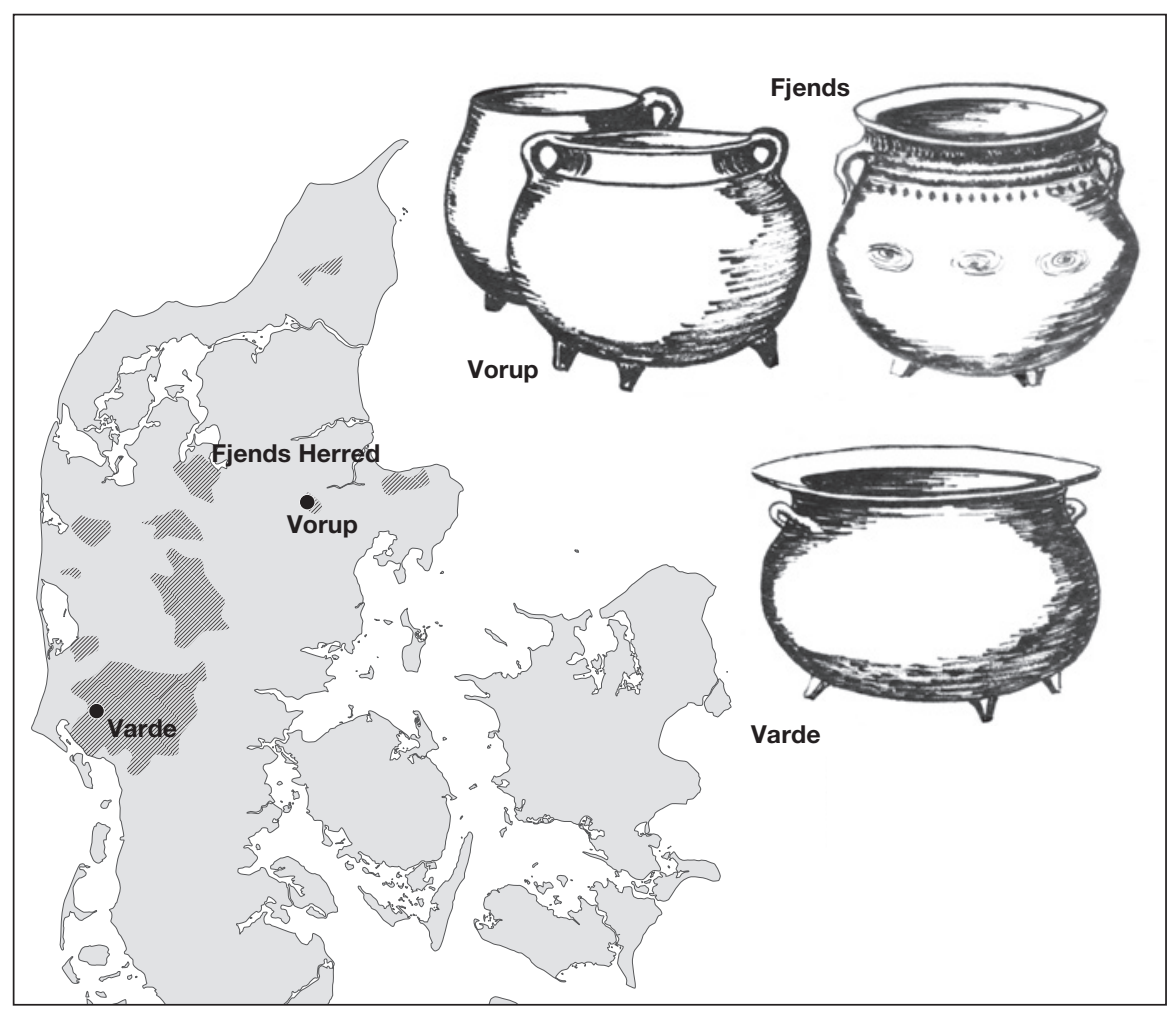

Fig. 1. Den yngre jydepottetraditions typiske karform i henholdsvis Vorup, Fjends og Varde. - Efter: L. Barfod 1966, s. 8.

Characteristic vessel types of the later Jydepotte-tradition as produced in Vorup, Fjends and Varde. 


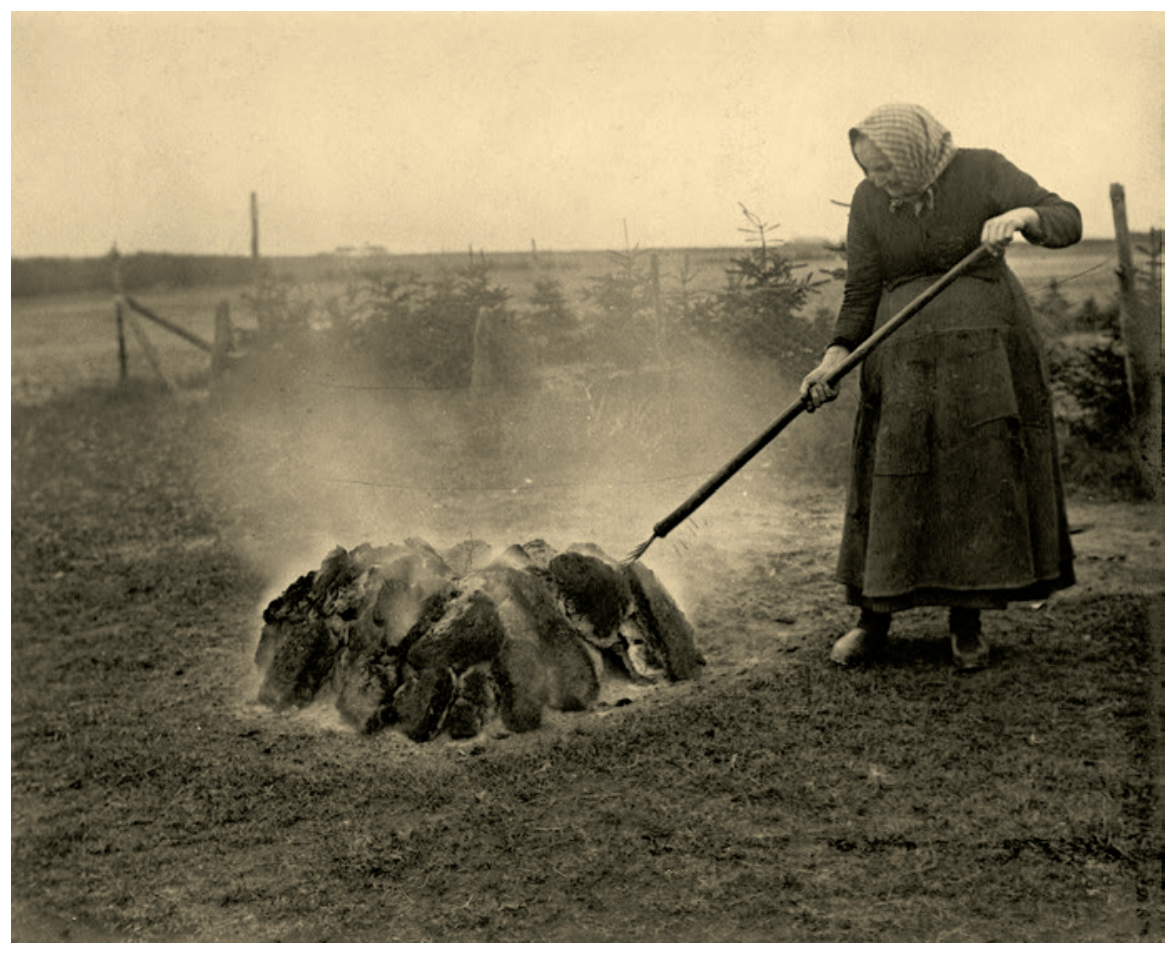

Fig. 2. Brænding af jydepotter i mile omkring 1920. - Foto: H.P. Hansen, Herning Museum.

Pit-firing of Jydepotter around 1920.

reret med glittede mønstre eller med glittet rand, hals og inderside. Den typiske form udgjordes af et rundbuget kar med to ører og tre tæer - en form der i nyere tid først og fremmest blev benyttet som koge- og opbevaringskar til mad, men også til adskillige andre funktioner for eksempel farvning af tøj. ${ }^{6} \mathrm{I}$ løbet af den lange produktionstid gennemgik de klassiske jydepotter lokalt kun en beskeden udvikling i former, og kar med den brede, flade rand optrådte fra start til slut.?

Fælles for karrene i de fire lokalområder var, at de blev brændt ved forholdsvis lave temperaturer i tildækkede miler, fig. 2. I flere af produktionsområderne var en vigtig del af fremstillingsprocessen derudover røgningen, der fandt sted før den egentlige brænding i milen. Selvom røgningen i 1800- og 1900-tallet blev kaldt å brån, var der ikke tale om en egentlig brænding, men snarere en langsom rygning over tre-fire dage, der på grund af tjærepartiklerne frembragte en mørkbrun farve og helt tørre kar. Denne proces fandt ved Varde sted i dertil byggede røgovne - $\propto$ brån hus. En lignende røgning af kar- 
rene kendes fra Fjends, hvor karrene inden brændingen stod nogle timer over røgen i husets skorsten, men fra de øvrige produktionsområder kendes den ikke. ${ }^{8}$ Pottekoner fra Varde har beskrevet, at røgningen gav karrene den rette sorte farve. Da der var tale om lave temperaturer i røgovnen på omkring 100 grader, brændte de mørke partikler fra tjæren bort ved den efterfølgende brænding i det nedgravede og tildækkede bål. Denne brænding var reduceret og resulterede derfor i sorte kar. Men måske har røgningen - som pottekonerne også fremhævede - gjort karrene tættere, fig. 3. ${ }^{9}$

Forskningshistorisk har jydepotterne først og fremmest været behandlet $\mathrm{i}$ forhold til henholdsvis dokumentation af karrenes fremstilling omkring det forrige århundredeskifte og karakteren af produktion og handel i 1600-1800-tallet i samtiden og efterfølgende ud fra skriftlige kilder. Men med publikationen "Keramik, kultur og kontakter. Køkken- og bordtøjets brug og betydning i Jylland 1350-1650" har Jette Linaa i 2006 med et arkæologisk udgangspunkt beskrevet keramikkens udvikling, brug, produktion og betydning i senmiddelalderen og renæssancen - deriblandt jydepotterne. Jette Linaas arbejder viser, at de tidligste jydepotter kan dateres til begyndelsen af 1400-tallet og måske allerede slutningen af 1300-tallet i det sydlige Østjylland. I Vestjylland

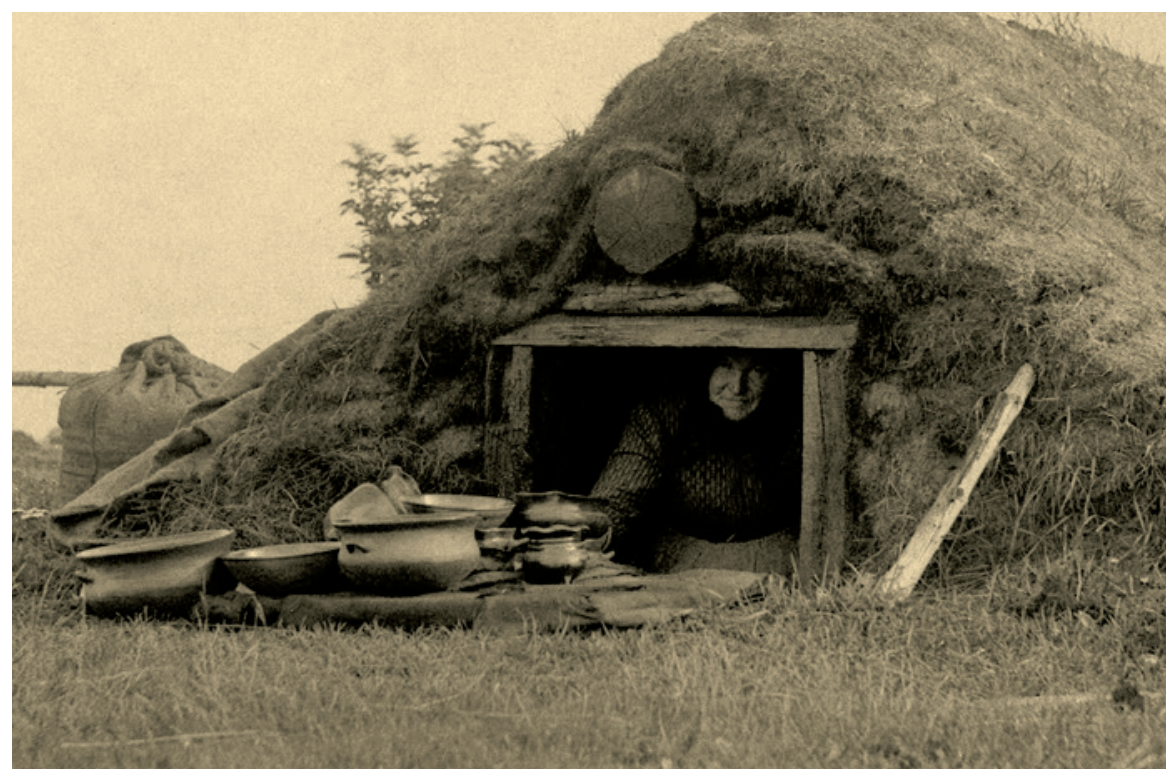

Fig. 3. De røgede kar tages ud af Marie Haugstrups røghus i Stilbjerg, 1914. - Foto: H.P. Hansen, Herning Museum.

The newly-smoked vessels are taken from the smokehouse, Stilbjerg 1914. 
ses de ældste sikkert daterede jydepotter i Ribe i starten af 1400-tallet, og også her er det muligt, at typen er endnu ældre og har rødder i 1300-tallet. ${ }^{10}$

Dermed er der kastet lys over den tidligste fremstilling af jydepotter, ligesom der er skabt forbindelse imellem den ældre arkæologisk belyste og den yngre produktion. På baggrund af det arkæologiske materiale fra 1400-1600-tallet udskiller Jette Linaa et antal lokalgrupper, der stort set stemmer overens med de grupperinger, der kendes fra senere tider. ${ }^{11}$ Det tyder altså på, at den nyere, velbelyste jydepotteproduktion har rødder i senmiddelalderens og renæssancens jydepottetradition. Både ligheder i formgivning, farve, brændingens karakter og udbredelse i lokale varianter indikerer, at betegnelsen af karrene fra 1300-, 1400- og 1500-tallet som jydepotter er anvendelig. ${ }^{12}$

\section{Keramikfremstilling som funktionel tilpasning eller kulturelle valg}

Jydepotterne er ofte sammenlignet med den forhistoriske keramikfremstilling, blandt andet fordi produktionsform og fremstillingsteknikker for den yngre jydepottetradition både er mulige og i mange tilfælde sandsynlige for keramikfremstilling i forhistorisk sammenhæng. Derudover ligner de sortbrændte glittede hankekar fra romersk jernalder delvist jydepotterne, som illustreret af keramikeren Finn Lynggaard i bogen "Jydepotter og ildgrave". ${ }^{13}$ Men med en tidsmæssig forskel på ca. 1.200 år er sammenligningen ikke indlysende..$^{14}$ Hverken reduceret brænding eller glitning er fremstillings- eller dekorationsmetoder, der specifikt er forbeholdt jydepotterne og jernalderkeramikken. Glitning ses blandt andet på hårdt brændte kuglepotter fra 1300-tallet. ${ }^{15}$ Sammenkædningen mellem jydepotterne og den forhistoriske keramik afspejler blandt andet en udbredt opfattelse af den forhistoriske keramikfremstilling som stabil og ensartet på tværs af tid og sted med ressourcer og naturgivne begrænsninger som de afgørende determinanter. ${ }^{16}$

Hertil udgør den etnologisk veldokumenterede jydepottefremstilling en vedkommende parallel. Ligesom der er lokalgrupper i jydepotternes form og dekoration, er der også forskelle i fremstillingsprocessen. Det gælder både konstruktionen af ildgrave og tørringen/røgningen af karrene, hvor den forholdsvis store arbejdsindsats i konstruktionen af røgovne havde en begrænset betydning for resultatet af det færdige kar. Den ovnkonstruktion, der blev benyttet til tørring af karrene på Vardeegnen, var tilsyneladende ikke nødvendig i de øvrige fremstillingsområder for jydepotter. Dermed havde væsentlige dele af fremstillingsprocessen i Varde ikke afgørende betydning for karrenes egenskaber eller produktionsformen. Det viser, at fremstillingen af jydepotter, 
ligesom form og udsmykning, også er udtryk for en række kulturelt tilegnede valg. Det er relevant i forståelsen af den forhistoriske keramikproduktion, hvor tilstedeværelsen af mulige ovnkonstruktioner ofte har været afvist ud fra økonomiske og rationelle betragtninger om produktionens størrelse, tilgængelige ressourcer og materialernes egenskaber. ${ }^{17}$

Mens stil - forstået som "a highly specific and characteristic manner of doing something... that is always peculiar to a specific time and place"18 - som et kulturelt såvel som kommunikativt udsagn længe har været fremhævet for lerkars udformning og dekoration, har stil i mindre grad været inddraget i forståelsen af de processer, der udgør fremstillingen af karrene. Fremstillingen af den forhistoriske keramik er derimod ofte blevet beskrevet som pottemagerens tilpasning til teknologiske, naturgivne og funktionelle love og en opfattelse af, at disse love - som fx lerets sammensætning, thermal shock, fordampning, spilderisiko, godsets tykkelse i forhold til opvarmningshastighed o.l. begrænsede og styrede både fremstillingsproces og karrets form..$^{19}$ Men de teknologiske aspekter af keramikfremstillingen er, ligesom dekoration og udformning, udtryk for både kulturelle, økonomiske og funktionelle strukturer i interaktion med aktørernes valg. ${ }^{20}$ Med begrebet "isokretisk stil" - forstået som det, der ligger ud over funktion - har James Sackett med en dialektisk forståelse af forholdet mellem funktion og stil beskrevet, hvordan stil er til stede, når der er et valg mellem to eller flere lige funktionelle muligheder, hvilket oftest er gældende for alle dele af fremstillingsprocessen. ${ }^{21}$ Derfor er der også grundlag for i større grad at vurdere teknologiske karakteristika og forandringer i produktionsformer - i denne sammenhæng fremkomsten af jydepottetraditionen - som resultatet af kulturelle og sociale forhold.

At ligheden mellem jydepotterne og den forhistoriske keramik stadig i nyere tid hyppigt fremdrages, ${ }^{22}$ skyldes nok ikke så meget en konkret opfattelse af en direkte forbindelse mellem jydepotterne og den forhistoriske keramik, men at jydepottetraditionen i produktionsform og teknik så markant adskiller sig fra den mere specialiserede produktion af henholdsvis den samtidige glaserede, rødbrændte keramik og den forudgående hårdt brændte gråvare.

\section{Højmiddelalderens keramik - flere sideløbende produktionsformer}

Gråbrændt keramik, først og fremmest i form af kuglepotter, ses talrigt i Vestdanmark fra slutningen af 1100-tallet til 1400-tallet, med den yngste sikre datering omkring $1450 .{ }^{23}$ De regelmæssige og oftest hårdt brændte og drejede kar vidner om en produktion af større omfang, hvilket også ovne og større 
fund af fejlbrændt keramik viser. Denne produktionsform kan betegnes som pottemagerværksteder (workshop industries), af David Peacock karakteriseret ved, at produktionen henvender sig til et marked, og at både høj kvantitet og kvalitet er essentielt, hvorfor ovn og drejeskive ofte benyttes. Erhvervet udgør det substantielle i husholdningen, muligvis med landbrug eller andet som et bierhverv. ${ }^{24}$

At keramikken fundet i de højmiddelalderlige ovne og fejlproduktioner henvender sig til et marked er overvejende sandsynligt på grund af både produktionens størrelse og ensartethed i typer og udformning. Ovnene er fundet i landbebyggelser, og karrene er sandsynligvis afsat til lokale landsbyer, klostre og borge, måske via markeder. ${ }^{25}$ Keramikken fra Barmerovnen kunne således både formmæssigt og ud fra lerets sammensæetning forbindes med et større antal skåle fundet på voldstedet Hedegård $10 \mathrm{~km}$ fra ovnen, ligesom dele af en kande fra klosteret Tvilum både morfologisk og ud fra lerets og magringens struktur stort set var identisk med keramikken fra Kragelundovnen. ${ }^{26}$

Kuglepotter og den samtidige blyglaserede keramik er fundet sammen i ovne og fejlbrændinger, hvilket viser, at de to godstyper tilsyneladende i flere tilfælde blev fremstillet under ens produktionsforhold af samme pottemager. ${ }^{27}$ Det er umiddelbart et udtryk for en kuglepotteproduktion af professionel karakter. Men med hensyn til karrenes opbygning er billedet varieret. Således er karrene fra Hellumovnen i Himmerland fra omkring år 1200 formentlig udelukkende trukket og banket op, en teknik, der ligger tæt på jydepotternes fremstillingsmetode.$^{28}$ En anden håndformet opbygningsmetode ses i keramikken fra Barmerovnene i Nordjylland fra slutningen af 1300-tallet, hvor karrene er pølset og banket op. ${ }^{29}$ Fra Kragelundovnen ved Silkeborg er keramikken fra 1300-tallet ikke tilsat magring og er pølset op til skulderpartiet, hvorefter halsen er drejet, mens andre samtidige kar er både helt eller delvist drejede, fig. $4 .{ }^{30}$

Med forbehold for det tidsmæssige og geografiske spænd vidner variationerne i opbygningsmetode om, at der ikke over større områder har været konsensus i opfattelsen af den rette fremstilling af karrene, men snarere forskellige kulturelt tilegnede ubevidste håndværksmæssige handlemønstre (motorhabits). Dermed er der måske ikke tale om en forbundet gruppe af pottemagere, hvorigennem traditioner og læringsprocesser videreføres og spredes gennem oplæring over større områder, men forskellige lokalt forankrede fremstillingstraditioner.

Netop keramikkens opbygningsmetode er særligt underlagt de motorhabits, som pottemageren har tilegnet sig ved oplæring i håndværket, mens tilberedning af ler samt dekoration og brænding af kar er processer og udtryk, der i 


\begin{tabular}{|c|l|l|l|l||}
\hline & Pølset op & $\begin{array}{l}\text { Banket/ } \\
\text { trukket op }\end{array}$ & $\begin{array}{l}\text { Pølset/banket op. } \\
\text { Efterfølgende sted- } \\
\text { vis roterering/drej- } \\
\text { ning, gerne af hals }\end{array}$ & Helt drejet \\
\hline $\begin{array}{l}\text { 1200- } \\
\text { tallet }\end{array}$ & & $\begin{array}{l}\text { Horsens fase 1b } \\
\text { (Linaa 1995: 211). } \\
\text { Ladegårdsmark (Lieb- } \\
\text { gott 1978:20) }\end{array}$ & $\begin{array}{l}\text { Fredsø (Birkals \& } \\
\text { Bugge Vegger 2001: } \\
123)\end{array}$ \\
\hline $\begin{array}{l}\text { 1300- } \\
\text { tallet }\end{array}$ & $\begin{array}{l}\text { Barmerovnene (Kock } \\
\text { 2001: 110; Lindahl } \\
\text { 2001:295). } \\
\text { Kragelund (Jessen } \\
\text { 2001: 113) }\end{array}$ & $\begin{array}{l}\text { Horsens delvis fase } \\
\text { 2, 3 \& 4 (Linaa 1995: } \\
\text { 214-216). Fjand } \\
\text { (Linaa 2006:69) }\end{array}$ & $\begin{array}{l}\text { Barmerovnene (Kock } \\
\text { 2001: 110; Lindahl } \\
\text { 2001: 295). } \\
\text { Kragelundovenen } \\
\text { (Jessen 2001: 113). }\end{array}$ & $\begin{array}{l}\text { Illerup Ådal (Søvsø } \\
\text { 2001: 147-148). Åle } \\
\text { (Birkals 2001: 159- } \\
160) .\end{array}$ \\
& & $\begin{array}{l}\text { Farum Lillevang } \\
\text { (Liebgott 2001: 131). } \\
\text { Lindholtgård (Bodil- } \\
\text { sen 2001: 181). } \\
\text { Horsens fase 2,3 \& } \\
\text { 4 (Linaa 1995: 214- } \\
\text { 216), }\end{array}$ & \\
\hline
\end{tabular}

Fig. 4. Variationer i opbygningsmetoder for kuglepotter i 1200-1300-tallet.

Variations in fashioning techniques for vessels from c. 1200-1300.

højere grad er synlige, hvorfor disse forhold i etnografisk sammenhæng ofte er tilpasset eller ændret i forhold til læringstraditionen. ${ }^{31}$ Selvom kuglepotterne fremstilles med salg for øje, og der eksisterer en udbredt brug af ovne til brændingen, er der ikke nødvendigvis tale om professionelle fuldtidspottemagere. Produktionen kan have haft en begrænset karakter som et bierhverv. I midten af 1800-tallet var pottemageriet således et bierhverv til landbruget for langt de fleste pottemagere i Sorring ved Silkeborg, ligesom mange af de praktiserende pottemagere her ikke selv havde ovne, men i stedet lejede sig ind hos andre pottemagere, når karrene skulle brændes. ${ }^{32}$ En lignende model kunne måske forklare variationerne i kuglepotternes opbygningsmetode.

At der ikke alene er tale om en ensartet og professionel pottemagerproduktion, fremgår af Helle Henningsens og Jette Linaas beskrivelser af forekomster af blødt eller mellemhårdt brændt keramik i 1200- og 1300-tals-sammenhæng i Vest- og Sønderjylland. Denne godstype ses for eksempel på de middelalderlige landhustomter Koustrup og Fjand i nærheden af Ringkøbing fra 1200-årene, fig. 5. ${ }^{33}$ Jette Linaa tolker denne keramiktype som en lavteknologisk hjemmeproduktion af kar ved siden af en hel- eller halvprofessionel keramikproduktion. Noget tilsvarende har også Niels-Knud Liebgott og Jesper Hjermind fremført om produktionen af østersøkeramik. Men kun et mindre antal fund af blødt til 


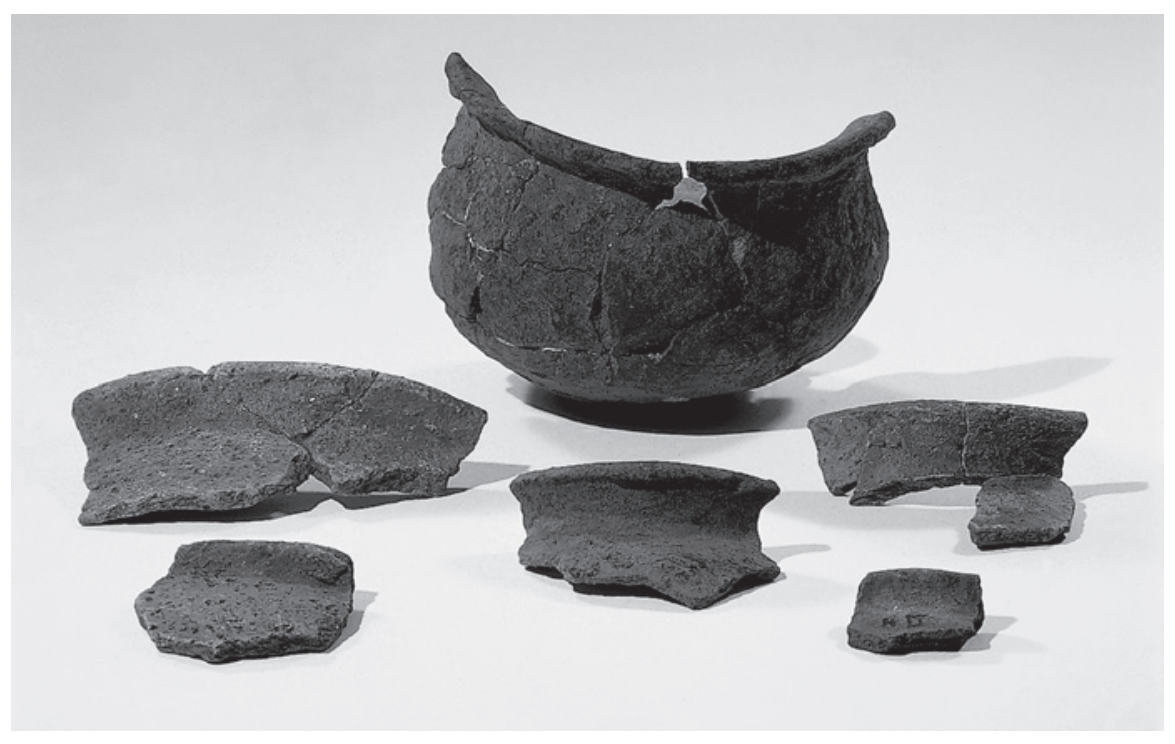

Fig. 5. Kuglepotter fra Fjand. - Foto: Jørgen Borg, Ringkøbing-Skjern Museum.

Vessels from Fjand.

mellemhårdt brændt gråvare bekræfter dette. ${ }^{34} \mathrm{Er}$ der så tale om en begrænset produktionsform eller en manglende opmærksomhed på fænomenet?

Den forskningshistoriske opfattelse af en brat overgang mellem den blødt og den hårdt brændte gråvare omkring år 1200 har skabt en reel mulighed for fejlplaceringer af en mulig blødt brændt vare i 12-1300-årene. ${ }^{35}$ Og selvom keramikkens brændingsgrad ofte forholdsvis let kan erkendes, er vurderingen af den subjektiv selv ved standardiserede metoder som Mohsskalaen. ${ }^{36}$ Derudover er blødt - eller med et ladet udtryk dårligt - brændt keramik porøst og vil være sværere at erkende og hjemtage end en hårdere brændt vare, hvilket kan føre til underrepræsentation både bevaringsmæssigt og ved optagelse, vask og registrering. Da keramikken fra Koustrup og Fjand antyder, at der som i den yngre jydepottetradition kan være tale om en fremstillingsmetode, der hører hjemme i landbebyggelser, kan også forskellige deponeringsforhold for affald $i$ henholdsvis land og by udgøre en fejlkilde.

Hvis vi vender blikket mod syd, optræder gråvaren i hele Nordvesteuropa først og fremmest i form af kuglepotter. I sin omfangsrige gennemgang af den middelalderlige keramikproduktion i Nordeuropa beskriver Hartwig Lütdke detaljeret forekomst og fremstillingsforhold for den yngre gråvare fra ca. år 1200-1500. Varen karakteriseres af forskellige fremstillingsmetoder, og håndopbyggede og drejede kar optræder side om side. Det samme er ifølge Hartwig 
Lütdke tilfældet for brændingsmetoder og dermed sandsynligvis også produktionsformer. Han mener, at der fra 1200-1500 sideløbende eksisterer en professionel produktion og en hauswerksproduktion, om end den professionelle dominerer. ${ }^{37}$ Om skiftet mellem keramikkens brændingsgrad i Aarhus, kommenterer han: "Bemerkenswert ist eine von Madsen festgestellte, sehr kurze und plötzliche Ablösungsphase der älteren weichen, durch de jüngeren harte Grauware vom Horizont 1 zum Horizont $2 . . .{ }^{38}$ I de nordtyske byer er denne overgang ikke brat, men derimod langsom. ${ }^{39}$

Selvom fundmaterialet i højmiddelalderen domineres af den hårdt brændte vare, er det således også i Danmark muligt - som variationen i opbygningsmetoder og fund i Vest- og Sønderjylland tyder $\mathrm{pa}^{\circ 0}$ - at der som i det øvrige Nordvesteuropa stedvis er tale om sideløbende eller mere varierede produktionsformer. Det scenarie gør skiftet i fremstillingsteknikker for produktionen af kuglepotter og jydepotter mindre markant.

\section{En tidlig jydepotteproduktion rettet mod salg?}

Mens omfanget af produktion og handel er mindre klar for jydepottetraditionens tidlige faser, er disse forhold velbelyst for den yngre tradition. Flere har beskæftiget sig med dennes karakter, der betegnes som en hjemme- eller protoindustri. Dermed menes et sideerhverv af betydeligt omfang i landlige regioner med afsætning til andre regioner eller internationale markeder, ${ }^{41}$ en karakteristik der først og fremmest beskriver den yngre produktion, mens den var på sit højeste. Den udenlandske pottehandel dokumenteres første gang i 1633, hvor et fartøj fra Kolding sejlede en ladning jydepotter til Femern. Allerede i 1643 havde 12 ud af 15 skibe fra Vardeegnen med kurs mod Nordtyskland sorte potter om bord. ${ }^{42}$ Historikeren Mette Guldberg har tolket den udenlandske jydepottehandel i 1600-tallet som en nichevirksomhed i forsendelsen af fødevarer mod syd, blandt andet som ekstravarer på skibene. Da eksporten af fisk og stude reduceredes, samtidig med at det blev forsøgt at centrere landets handel fra København, fik den mindre nichehandel med jydepotter så stor betydning, at den var blandt de tre største handelsvarer i Vestjylland i 1700 -årene. ${ }^{43}$ Den udenlandske jydepottehandel indgik dermed belejligt som en ekstra eksportvare $\mathrm{i}$ et allerede etableret handelsnetværk.

Tilvejebringelsen af fisk til eksport fandt i Sydvestjylland blandt andet sted ved fiskerlejet og handelspladsen Sønderside, der var ramme om et livligt sæsonfiskeri og handel fra marts til juni i 1400- til 1600-årene, indtil området i 1634 blev ødelagt af stormflod. ${ }^{44}$ Arkæologiske undersøgelser af dele af den store handelsplads har bragt mange skår af jydepotter for dagen såvel som 
rødbrændt, glaseret keramik og skår af importerede kar. ${ }^{45}$ Karrene fra denne plads, hvoraf mange har været af jydepottegods, kendes fra skriftlige optegnelser fra midten og slutningen af 1500-tallet, hvor kander med øl blev serveret i boderne, såvel som brugt til at slå med under stridigheder. ${ }^{46}$ Der var helårsboliger på Sønderside, men størstedelen af pladsen bestod af mindre fiskerhytter eller sæsonboder. ${ }^{47}$ Pladsens fiskeri- og handelsmæssige karakter taget i betragtning er det sandsynligt, at de store mængder jydepottegods ikke blev fremstillet på pladsen. Blandt andet var sæsonfiskeriet samtidig med store dele af pottefremstillingen, som den kendes etnologisk. Snarere var der nok tale om handelsvarer allerede i starten eller midten af 1500-tallet. At karrene blev handlet lokalt antydes også af, at der ikke er forskel på jydepotter fra henholdsvis Sønderside og Ribe i hverken former eller overfladebehandlinger. ${ }^{48}$

De ældste sikre optegnelser om hjemlig handel med jydepotter stammer fra 1562 og 1583, hvor grydemænd fra Skive og et fartøj fra Vejle betalte bropenge for at transportere sorte potter til henholdsvis Aalborg og Skælskør. Først fra 1600-tallet bruges betegnelsen jydepotter, mens karrene i produktionsområderne også herefter fortsat kaldtes sorte potter. ${ }^{49}$ Allerede på denne tid var der tale om en handel af større omfang og over betydelige områder. Handelen vidner om, at produktionen af jydepotter i det mindste nogle steder må have været af et vist omfang i midten og slutningen af 1500-tallet og måske tidligere.

Indtil 1420'erne ses skår af det tidlige jydepottegods kun i landlige miljøer. ${ }^{50}$ Det beskedne kildemateriale taget i betragtning, peger det forhold på, at den tidlige produktion hørte hjemme i landbebyggelsen. Det kunne være i form af en husholdningsproduktion (household production) kun til gårdenes eget forbrug, ${ }^{51}$ eller et husholdningserhverv (household industry) rettet mod salg sekundært til landbrug eller andet erhverv. Forekomsten af jydepotter i bysammenhæng fra 1420'erne og frem antyder måske en handel med karrene eller deres indhold allerede på dette tidspunkt. Tilsvarende ses husholdningsproduktioner af keramik alene til eget brug kun sjældent i etnografisk sammenhæng. ${ }^{52} \mathrm{Og}$ da jydepotterne fra midten og slutningen af 1500-tallet og frem netop karakteriseres af at være en salgsvare, er en mindre produktion som bierhverv heller ikke utænkelig for den tidlige produktion.

\section{Pest, potter og sociale og økonomiske omvæltninger}

I 1400-tallets begyndelse finder der en gradvis ændring sted i den hjemlige keramikproduktion i udformning, teknik og produktionsformer. Denne ændring karakteriseres af produktionen af blødt brændte, håndopbyggede jydepotter i løbet af 1400-tallet samtidig med, at produktionen af de oftest hårdt 
brændte og drejede kuglepotter aftager. Sideløbende hermed koncentreres en mere professionel produktion af glaserede kar i løbet af 1400- og 1500-tallet i byerne. Hverken produktionsformerne på Fyn, Sjælland eller i Tyskland peger på, at ændringen skulle have inspiration i forandringer i omkringliggende områder. ${ }^{53} \mathrm{Og}$ da det netop er en mindre, sandsynligvis husholdningsforankret, produktion der vinder frem, kan det være ændringer af økonomiske og sociale forhold internt i Jylland, der skabte betingelserne for, at jydepotteproduktionen afløste den mere professionelle produktion af hårdt brændte kuglepotter.

I 1349 blev Danmark for første gang ramt af pesten. Hvor kildematerialet om den sorte død og de efterfølgende pestepidemier i 1300-tallets anden halvdel i Danmark er fåtallige, er følgerne bedre belyst i England, Norge og Tyskland. Her resulterede pestepidemierne flere steder i, at op $\bmod 40-50 \%$ af befolkningen døde inden for få årtier. ${ }^{54}$ Optegnelser over dødeligheden i Hamburg efter den sorte død beretter, at 12 ud af 34 bagermestre døde, 18 ud af 40 slagtere og 21 ud af 37 stadsfunktionærer. ${ }^{55}$ I Danmark vidner blandt andet anniversarierebøgerne fra Ribe Domkirke om tab under den sorte død, ligesom forladte gårde, huse og jord i de følgende årtier er udsagn om pestens følger. ${ }^{56}$ Den store affolkning betød - ud over den menneskelige tragedie - en markant forandring af produktionsforholdene på landet og i byen. Både i Danmark og det øvrige Europa betød en stor befolkningstæthed før pesten, at der i tiden lige efter den sorte død var folk til at overtage forladte gårde, huse og jord. Men de langsigtede konsekvenser af den høje dødsrate, sandsynligvis forstærket af den gentagne effekt af efterfølgende epidemier, slog først for alvor igennem omkring år $1400 .{ }^{57} \mathrm{Ud}$ over epidemier og dermed følgende befolkningsnedgang og mindre arbejdskraft kan disse ødelæggelser have været forværret af klimaændringer og markante prisforskelle på korn i Europa. ${ }^{58}$

Denne krise omkring år 1400 er samtidig med de begyndende ændringer i produktionsforholdene for den hjemlige keramik. Krisen førte ikke kun til forarmelse, men også til nye muligheder. Det er derfor nærliggende at se forandringerne i produktionsform, udformning og teknik i den danske keramikproduktion på denne tid i lyset af pesten og de samfundsmæssige ændringer, der fulgte i tiden derefter. I England er lignende forandringer i keramikproduktionen efter pesten dokumenteret. I slutningen af 1300-tallet fortrængtes i England således den drejede, dekorerede keramik af en grovere håndopbygget vare.$^{59}$ Netop den sorte død er her blevet foreslået som årsag til, at pottemagerproduktioner af drejet og rigt dekoreret keramik nogle steder blev udslettet, mens fremstillingen andre steder fortsatte stærkt reduceret. ${ }^{60}$ Forandringerne i den engelske keramiks udseende og opbygning er af Jean Le Patourel blevet 
tolket som resultat af, at pottemagererhvervet overgik fra en produktion af mere professionel karakter til et husholdningserhverv udført af mænd, hvis hovedinteresse var landbrug. ${ }^{61}$ Denne udvikling kan have ligheder med situationen i Danmark på samme tid. At samfundsændringer forårsaget af pesten kunne få betydning for håndværkstraditioner, ses også i Norge i forbindelse med huggeteknikken sprett-telging, der blandt andet blev anvendt til skibsbyg-

ning og bygning af kirker. Denne tekniks forsvinden omkring 1350 er tilsvarende blevet tolket som værende relateret til konsekvenserne af den sorte død. ${ }^{62}$

Det er dermed en mulighed, at ændringerne og omlægningen i tiden omkring år 1400 af produktionen af både den uglaserede og glaserede keramik i Danmark også var påvirket af befolkningsnedgang og de sociale og økonomiske forandringer, der fulgte. På baggrund af de relativt få danske ovnfund ser det ud til, at den landligt forankrede højmiddelalderlige keramikproduktion i løbet af senmiddelalderen flyttes til byerne, og at denne produktion omlægges til udelukkende at være koncentreret om glaserede kar, men i et bredere repertoire end før. Den voksende kakkelproduktion i 1400- og 1500-tallet ${ }^{63}$ kan også have forstærket bypottemagernes specialisering i den glaserede keramik. Dermed opgives gradvist en del af de sandsynligvis halv- eller helprofessionelle pottemageres produkter - den gråbrændte husholdningskeramik. Det sker, selvom efterspørgslen efter denne keramiktype ikke ser ud til at have aftaget. Faktisk er forbruget af gråbrændt keramik stort i både byer og på landet. ${ }^{64}$ Den tidlige jydepotteproduktion kan dermed ses som et forsøg på at imødekomme en efterspørgsel efter billige husholdningskar i kølvandet på en reduceret mere professionel produktion.

\section{Årsager til forandring}

Overgangen fra kuglepotter til jydepotter i den første halvdel af 1400-tallet markerer både et formmæssigt og et teknisk skifte, som i kronologisk henseende meget vel kunne være blevet tolket, hvis ikke som udtryk for et periodisk skifte, så i hvert fald som grundlag for en faseinddeling. At dette ikke har været tilfældet, skyldes for det første, at den nøjagtige overgang mellem de to typer - såvel som 1400-tallets hjemlige keramik generelt - ikke har været tydelig. ${ }^{65}$ Først i de senere år er det blevet klart, at fremstillingen af jydepotter kan føres tilbage til slutningen af 1300-tallet og starten af 1400-tallet. ${ }^{66}$ Derudover har særligt den ikke-lokale middelalderlige keramik været vægtet højt, ligesom keramikkens udsagn åbenlyst har en mindre fremtrædende rolle i forståelsen af yngre perioder, der kan belyses gennem et større udvalg af kilder. Ikke desto mindre falder starten på forandringerne i den gråbrændte keramiks udform- 
ning, fremstillingsteknikker og produktionsform omtrent sammen med overgangen fra høj- til senmiddelalder. At forandringer i materiel kultur over tid afspejler samfundsmæssige ændringer, der kan betegne periodeovergange, er et grundlag for den kronologiske genstandsforskning. Og når der er overensstemmelse imellem ændringer i flere forskellige kontekster på samme tid, sandsynliggør det, at disse ændringer faktisk afspejler samfundsmæssige forhold. ${ }^{67}$

I det ovenstående tolkes ændringerne i den gråbrændte keramiks form og fremstillingsmetode som relateret til de samfundsmæssige forandringer, der fandt sted omkring år 1400 blandt andet som følge af den sorte død og 1400-tallets krise. Denne tolkning er ikke en argumentation for, at ændringer i keramikkens dekoration, udformning og produktionsform generelt skal søges i katastrofer eller drastiske demografiske forandringer. ${ }^{68}$ Snarere skal ændringerne ses i lyset af både en række kulturelle og økonomiske omstændigheder, der her udmundede i en omlægning af produktionsforholdene.

\section{Afrunding}

Keramikfremstilling foregår inden for de kemiske og fysiske rammer, der er mulige i forhold til lerets sammensætning, magringens art og brændingsforhold. Men de tekniske dele af selve fremstillingen er også socialt forankrede, har rod i bestemte læringsprocesser og kan relatere til for eksempel symbolske eller økonomiske forhold. Ovenfor er det foreslået, at et gradvist skifte i fremstillingsmetoder og produktionsformer for den hjemligt gråbrændte keramik omkring år 1400 netop skal ses som konsekvens af de sociale og økonomiske forandringer, der slog igennem på denne tid som følge af pesten og 1400-tallets krise, en forklaring, der også er blevet fremhævet for et tilsvarende skifte i keramikfremstillingen på samme tid i England såvel som for en samtidig ændring af håndværkstraditioner i Norge. Begyndelsen af jydepottetraditionen kan meget vel have sit udgangspunkt i en kontinuitet fra højmiddelalderen af mindre husholdningsproduktioner af keramik til eget forbrug. Men sammen med en variation i opbygningsmetoder for kuglepotterne, vidner den blødt brændte keramik i 1200-1300-tallet også om en vis grad af diversitet og måske fleksibilitet i højmiddelalderens keramikfremstilling. Med denne diversitet såvel som handel med jydepotter i 1500 -tallet og jydepotter i bysammenhæng fra 1420'erne og frem er allerede en tidlig jydepotteproduktion som et bierhverv ikke utænkelig. Og da jydepottetraditionens begyndelse falder sammen med 1400-tallets krise, er det en mulighed, at den tidlige produktion var en salgsrettet erstatning for eller alternativ til en reduceret eller ændret professionel keramikproduktion. 


\section{NOTER}

1. Guldberg 1999, s. 80-88.

2. F.eks. Sehested 1881, s. 21-23; Jensen 1924; Barfod 1966, s. 7; Lynggaard 1972, s. 3033 \& 88-89; Liebgott 1978, s. 42; Kristensen 2004, s. 221; Linaa 2006, s. 90.

3. Henningsen $2000 \& 2002$, s. 235; Linaa 2006, s. 127.

4. Linaa 2006, s. 86, 127; Henningsen 2002, s. 235; Hjermind 1998, s. 97-99 \& 117118.

5. Lynggaard 1972, s. 75-85.

6. Guldberg 1999, s. 45-50; Linaa 2006, s. 129-131.

7. Lynggaard 1972, s. 13-29; Linaa 2006, s. 67-86.

8. Lynggaard 1997, s. 39.

9. Lynggaard 1972, s. 36-37.

10. Linaa 1995 , s. 217-218 \& Linaa 2006, s. 80-83.

11. Linaa 2006, s. 84-87.

12. Linaa 2006, s. 86-87 \& 177; Jensen 1982, s. 101.

13. Lynggaard 1972, s. 88-89.

14. Hansen 1999, s. 32.

15. Linaa 2006, s. 69; Hjermind 1998, s. 95 \& 107.

16. Gosselain 1998.

17. F.eks. Hulthen 1984, s. 32; Stilborg 1993, s. 19; Stilborg 1995, s. 41; Koch 1998, s. 128-129.

18. Sackett 1977, s. 370.

19. F.eks. Juhl 1995; Hulthen 1977; Skibo \& Schiffer 1989.

20. Gosselain 1998.

21. Sackett 1982; Gosselain 1998.

22. F.eks. Barfod 1966, s. 7; Lynggaard 1972, s. 30-33 \& 88-89; Liebgott 1978, s. 42 ; Kristensen 2004, s. 221; Linaa 2006, s. 90.

23. Linaa 2006, s. 87.

24. Peacock 1982, s. 9 ff.

25. Jessen 2001, s. 119-121; Koch 2001d, s. 111-112; Linaa 2006, s. 127; Hjermind 1998, s. 117.

26. Koch 2001d, s. 111-112; Jessen 2001, s. 121.

27. Linaa 2006, s. 124; Jessen 2001, s. 116.

28. Koch 2001a, s. 17-26; Koch 2001c, s. 89-98.

29. Jessen 2001, s. 113; Lindahl 2001, s. 295.

30. Birkals \& Bugge Vegger 2001, s. 123; Søvsø 2001, s. 147-148.

31. Gosselain 1998.

32. Koch \& Schmidt 2001, s. 258.

33. Henningsen 2002; Henningsen 2000; Linaa 2006, s. 86.

34. Linaa 2006, s. 69-70 \& 178; Henningsen 2002, s. 235 \& 262; Henningsen 2000, s. 174; Hjermind 1998, s. 99 \& 117; Liebgott 1982, s. 136.

35. Madsen 1971; Liebgott 1978, s. 18-19 Liebgott 1989, s. 29; Hjermind 1998, s. 118.

36. Erdmann et al. 2001, s. 993.

37. Lütdke 2001, s. 172.

38. Lütdke 2001, s. 122.

39. Lütdke 2001, s. 158.

40. Linaa 2006, s. 86. 
41. Guldberg 1999, s. 33-34; Aaberg Madsen 1983, s. 103-106.

42. Guldberg 1999, s. 65-69, 87, 199.

43. Guldberg 1999, s. 199-200.

44. Holm 1998, s. 70.

45. Frandsen 1998, s. 62 ff.; Linaa 2006, s. 138-139.

46. Holm 1998, s. 73-74; Kristensen 1965, s. 89-90.

47. Frandsen 1998; Holm 1998.

48. Linaa 2006, s. 83.

49. Guldberg 1999, s. 35, 64.

50. Linaa 2006, s. 162.

51. Linaa 2006, s. 162; (Peacock 1982, s. 8 ff. for beskrivelse af produktionsformer).

52. Peacock 1982, s. 13.

53. Lütke 2001.

54. Hybel 1988, s. 322-, s. 330; Ulsig 1991, s. 26-31; Benedictow 1997, s. 100.

55. Reincke 1952/Ulsig 1991, s. 31.

56. Benedictow 1997, s. 100; Ulsig 1991, s. 33-38; Hybel 1988.

57. Hybel 1988, s. 330-331.

58. Gissel 1994; Orrman 1997.

59. Jensen 1993, s. 246; Cherry 1991, s. 207.

60. Cherry 1991, s. 204.

61. Efter Cherry 1991, s. 207; Jensen 1993, s. 246-247; Patourel, 1968, s. 114.

62. Marumsrud \& Falk 2009, s. 119-121.

63. Kristiansen 2008, s. 249-253.

64. Linaa 2006, s. 150.

65. Jensen 1982; 1993

66. Linaa 1995, 2006.

67. Jensen 2005, s. 31.

68. Se Rosenberg 2006, s. 37.

\section{LITTERATUR}

Barfod, L. 1966: Ingen nød i potteland. Skalk 1966:4, s. 7-11.

Benedictow, O.J. 1997: The Blach Death. I: P. Grinder-Hansen (ed.): Margrete I. Regent of the North. The Kalmar Union 600 years. Danmarks Nationalmuseum. København, s. 99-102.

Birkals, A. 2001: En affaldsbunke fra en pottemager i Åle. Præsentation af tendenserne i et keramikmateriale. Hikuin 28, s. 159-168.

Birkals, A. \& P. Bugge Vegger 2001: Pottemagerovnen i Fredsø. Hikuin 28, s. 49-52.

Bodilsen, A. 2001: Keramikken fra Lindholtgård. Hikuin 28, s. 177-186.

Cherry, J. 1991: Pottery and Tile. I: J. Blair \& N. Ramsey (eds.): English Medieval Industries. Craftsmen, techniques, products. London \& Rio Grande, s. 189-209.

Erdmann, W. et al. 2001: Rahmenterminologie zur Mittelalterlichen Keramik in Norddeutschland.I: H. Lüdtke \& K. Schietzel (eds.): Handbuch zur mittelalterlichen Keramik in Nordeuropa, Bd. 2. Schriften des Archäologischen Landesmuseums, Band 6. Neumünster, s. 947-969.

Frandsen, L. 1998: På jagt efter fiskerlejet Sønderside. Mark og montre 1998, s. 61-68.

Gissel, S. 1994: Forskningen i den senmiddelalderlige agrarkrise. Status og perspektiver. I: P. Ingesman \& J.V. Jensen (red.): Danmark i senmiddelalderen. Aarhus, s. 25-39. 
Gosselain, O.P. 1998: Social and Technical Identity in a Clay Crystal Ball. I: M.T. Stark (ed.): The Archaeology of Social Boundaries. Washington \& London, s. 78-106.

Guldberg, M. 1999: Jydepotter fra Varde-egnen. Produktion og handel ca. 1650-1850, Landbohistorisk Selskab. Kerteminde.

Hansen, M. 1999: Hvad kommer jydepotterne af? Mark og montre 1999, s. 29-38.

Henningsen, H. 2000: Middelalder i Fjand. Kuml 2000, s. 151-198.

Henningsen, H. 2002: Koustrup. En middelalderlig torp i Vestjylland. Kuml 2002, s. 221263.

Hjermind, J. 1998: Keramik. I: J. Hjermind, M. Iversen \& H.K. Kristensen (red.): Viborg Søndersø 1000-1300. Byarkcoologiske undersøgelser 1980 og 1984-85. Viborg Stiftsmuseums skriftrække bind 2/Jysk Arkæologisk Selskabs Skrifter XXIV. Højbjerg, s. 93121.

Holm, P. 1998: Sønderside. Mark og montre 1998, s. 69-80.

Hulthén, B. 1977: On ceramic technology during the Scanian neolithic and Bronze Age. Theses and Papers in North-European Archaeology, vol. 6. Stockholm.

Hulthén, B. 1984: Sluta leta efter förhistoriska keramikugnar. Populär Arkeologi, årg. 2: 4, s. 32.

Hybel, N. 1988: Ødelæggelser og økonomisk krise i nordvesteuropæisk senmiddelalder. I: P. Enemark, P. Ingesman \& J.V. Jensen (red.): Kongemagt og samfund i middelalderen: festskrift til Erik Ulsig på 60-årsdagen 13. februar 1988. Aarhus, s. 317-335.

Jensen, A.G. 1924: Jydepotten - Vort Lands aldste Haandvark. København.

Jensen, C.K. 2005: Kontekstuel kronologi - en revision af det kronologiske grundlag for forromersk jernalder i Sydskandinavien. LAG 7. Højbjerg.

Jensen, V. 1982: 1400-årenes lertøj i Kolding. Hikuin 8, s. 95-104.

Jensen, V. 1993: Historisk arkæologi. Hvor går grænsen? Fortid og Nutid 1993, s. 243-250.

Jessen, A.B. 2001: Keramikken fra Kragelund. Hikuin 28, s. 113-122.

Juhl, K. 1995: The Relation between Vessel Form and Vessel Function. A Methodological Study. AMS-Skrifter 14. Stavanger, s. 4-143.

Koch, E. 1998: Neolithic Bog Pots from Zealand, Møn, Lolland and Falster. København.

Kock, J. 2001a: Hellumovnen. En pottemagerovn fra ældre middelalder. Hikuin 28, s. 17-26.

Kock, J. 2001b: Barmerovnene. Pottemagerovne fra 1300-årene. Hikuin 28, s. 27-42.

Kock, J. 2001c: Keramikken fra Hellum. Hikuin 28, s. 89-98.

Kock, J. 2001d: Keramikken fra Barmer. Hikuin 28, s. 99-112.

Kock, J. \& L. Schmidt 2001: Pottemagerier og pottemagerovne. Etnologiske og etnografiske paralleller. Hikuin 28, s. 247-280.

Kristensen, H.K. 1965: Gamle sydvestjyske fiskerlejer. Historisk samfund for Ribe Amt. Varde.

Kristensen, H.K. 2004: Teknik. Keramik. I: E. Roesdahl (red.): Dagligliv i Danmarks middelalder. Aarhus, s. 218-221.

Kristiansen, O. 2008: Kakkelproduktion i Danmarks middelalder og renæssance. Kuml 2008, s. 245-285.

Liebgott, N.-K. 1978: Keramik fra vikingetid og middelalder. Nationalmuseet. København.

Liebgott, N.-K. 1982: Jernløsegård. En middelalderlig gårdtomt i Søndre Jernløse. Aarbøger for Nordisk Oldkyndighed og Historie 1980, s. 126-164.

Liebgott, N.-K.1989: Dansk Middelalderarkcologi. København.

Liebgott, N.-K. 2001: Keramikken fra Farum Lillevang. Hikuin 28, s. 127-138.

Linaa, J. 2006: Keramik, kultur og kontakter. Køkken- og bordtøjets brug og betydning i Jylland 1350-1650, Jysk Arkæologisk Selskabs Skrifter LVI. Højbjerg. 
Linaa Larsen, J. 1995: Skår i tusindtal - keramik fra torvet i Horsens ca. 1350-1650. Kuml 1995-1996, s. 207-237.

Lindahl, A. 2001: Laborativa analyser av keramik från Hellum, Barmer och Kragelund. Hikuin 28, s. 281-296.

Lüdtke, H. 2001: Grauware des 12. bis 15. jahrhunderts. I: H. Lüdtke \& K. Schietzel (eds.): Handbuch zur mittelalterlichen Keramik in Nordeuropa. Bd. 1 Text. Schriften des Archäologischen Landesmuseums, Band 6. Neumünster, s. 83-173.

Lynggaard, F. 1972: Jydepotter og ildgrave. København.

Madsen, H.J. 1971: Keramik. I: H.H. Andersen,, P.J. Crabb \& H.J. Madsen: Århus Søndervold - en byarkcologisk undersøgelse. Jysk Arkæologisk Selskabs Skrifter IX. Højbjerg, s. 64-105.

Mamsrud, H. \& E. Falk 2009: Da vi fant sprett-telging i Georgia. Katta på veggen - Maihaugens Arbok 2009, s. 119-121.

Orrman, E. 1997: The Agrarian Crisis and Its Consequences. I: P. Grinder-Hansen (ed.): Margrete I - Regent of the North. The Kalmar Union 600 years. Danmarks Nationalmuseum. København, s. 109-113.

le Patourel, H.E.J. 1968: Documentary Evidence and the Medieval Pottery Industry. Medieval Archaeology XII, s. 114.

Peacock, D.P.S. 1982: Pottery in the Roman world. An ethnoarchaeological approach. New York.

Rosenberg Andersen, A. 2006: Keramik - mere end bare skår? Arkcoologisk Forum 15, s. 36-39.

Reincke, H. 1952: Bevolkerungsprobleme der Hansestådte. Hansische Geschichtsblåtter 70 (1951), s. 7 ff.

Sackett, J.R. 1977: The meaning of style: a general model. American Antiquity 42, s. 369-80.

Sackett, J.R. 1982: Approaches to Style in Lithic Archaeology. Journal of Anthropological Archaeology 1, s. 59-112.

Sehested, F. 1881: Jydepotteindustrien. København.

Skibo, J.M., M.B. Schiffer \& K.C. Reid 1989: Organic-Tempered Pottery: An Experimental Study. American Antiquity 54, s. 122-146.

Stilborg, O. 1993: Pottemagerne fra Brudager. Årbog for Svendborg og Omegns Museer 1993, s. $16-23$.

Stilborg, O. 1995: En ugn är en ugn är en ugn. Om ugnar i allmänhet och en ugn från Skummeslöv, Halland i synnerhet. Meta 95:4, s. 39-48.

Søvsø, M. 2001: Pottemageraffald fra Illerup ådal. Hikuin 28, s. 147-158.

Ulsig, E. 1991: Pest og befolkningsnedgang i Danmark i det 14. århundrede. Historisk tidsskrift 91, s. 21-43.

Aaberg Madsen, L. 1983: En analyse af den hjemmeindustrielle produktion af jydepotter $i$ Øster Horne Herred i perioden 1750-1850. Utrykt Speciale, Aarhus Universitet, Historisk Institut 1983. 


\section{A new ceramic tradition}

\section{Social changes reflected in medieval pottery production}

Jutland's locally manufactured grey to black earthenware pots - so-called Jydepotter - constituted widespread consumer goods during the main period of their production from around 1400 to 1900 . Within this ceramic tradition, the typical vessel shapes and mode of production remained practically unchanged over a period of 500 years (figs. 1-2). However, it is unclear how the tradition started and, in particular, how this apparently local manufacture could take over from the existing more professional production of hard-fired and often wheel-thrown vessels.

The shift in production mode for grey wares has previously been explained in terms of a continuation of the local pitfired pottery production of the Early Middle Ages. The demonstration, within the last ten years, of the presence of this ware type has underlined the existence of local production on a restricted scale (fig. 5). Together with a large variation in fashioning techniques in hard-fired pottery production (fig. 4), a degree of diversity in the ceramic production of the High Middle Ages seems likely. Consequently, the transition to an early, probably locally-rooted Jydepotte-tradition appears less striking.

Rather than being a continuation of a medieval tradition of local pit-fired pottery, the Jydepotte-tradition has repeatedly been described as following on from prehistoric, predominantly Iron Age, pottery production. This comparison indirectly reflects a prevalent conception of the tech- nical aspects of ceramic production as being governed by ecological and functional constraints, leaving little room for cultural or social choices. But the ethnologically well-studied Jydepotte-tradition provides an example where considerable elements of the production process have little significance for either the properties of the vessels or their mode of production. It is thereby an expression of cultural style rather than functional adaptation (fig. 3).

In this article, the emergence of the Jydepotte-tradition is viewed in the light of the social and economic changes that took place around 1400. Extensive developments in technical craft traditions and ceramic production modes in Norway and England have been linked with the consequences of the Black Death and subsequent plagues. Changes in the production of both grey wares and of glazed red wares around 1400 in Denmark could have been similarly influenced by these circumstances. It seems likely that the vessels already constituted commercial items in the 16th century and this mode of production could have already existed from the beginning of the tradition. Accordingly, the early Jydepotte-tradition can be seen as a local attempt to meet the demand for cheap household vessels, constituting a competitive alternative to a declining professional production as a consequence of the Black Death and the social and economic changes that occurred around 1400 . 